ОРГАНИЧЕСКИЕ И ОРГАНО-МИНЕРАЛЬНЫЕ СОСТАВЛЯЮЩИЕ ФОСФАТНОГО РЕЖИМА ЭРОДИРОВАННЫХ ПОЧВ ЦЕНТРА РУССКОЙ РАВНИНЫ

(C) 2016 г. 3. С. Артемьева ${ }^{1}$, Н. П. Кириллова ${ }^{1,2}$, Т. М. Силева ${ }^{2}$ Е. И. Сошникова ${ }^{1,2}$

${ }^{1}$ Почвенный институт им. В.В. Докучаева, Россия, 119017, Москва, Пыжевский пер., 7, стр. 2 e-mail: artemyevazs@mail.ru

${ }^{2}$ МГУ им. М.В. Ломоносова, Россия, 119991, Москва, Ленинские горы, 1, стр. 12

Исследовано фосфатное состояние пахотных горизонтов эродированных почв зонального ряда центра Русской равнины на основе параметров сорбции фосфат-иона разных компонентов органического вещества. Показаны характеристики сорбции фосфат-иона органических и органоминеральных фракций для оценки фосфатного состояния эрозионнодеградированных почв. Органические и органо-минеральные фракции пахотных горизонтов несмытых почв зонального ряда характеризуются высокими уровнем подвижности фосфора и способности поддерживать постоянный уровень доступных для растений фосфатов: агродерновоподзолистые почвы $(17.9 \pm 1.0 \quad$ мг/кг $) \rightarrow$ агросерые почвы $(16.4 \pm 1.7$ мг/кг $) \rightarrow$ агрочерноземы $(15.5 \pm 1.1$ мг/кг). Количество сорбированного почвой фосфора составляет ряд: агродерново-подзолистые почвы $(96$ мг/кг) $\rightarrow$ агросерые почвы $(118$ мг/кг) $\rightarrow$ агрочерноземы (141 мг/кг). В сочетании с максимальной насыщенностью гумусом илистых фракций исследованного зонального ряда несмытых почв центра Русской равнины в условиях реальной экологической обстановки, полнопрофильные почвы можно считать наиболее устойчивыми к деградации. Агроэкологическими особенностями эродированных почв являются повышенная сорбция фосфат-иона, сорбционные характеристики меняются в сторону увеличения прочности связывания фосфат-ионов, уменьшения количества доступного растениям фосфора: для агродерново-подзолистых почв $10.8 \pm 0.2$ мг/кг, агросерых почв $9.2 \pm 0.6$ мг/кг, агрочерноземов $-9.1 \pm 1.8$ мг/кг. Содержание лабильного Фосфора составляет ряд: агродерново-подзолистые почвы (230 мг/кг) $\rightarrow$ агросерые почвы $(231$ мг/кг) $\rightarrow$ агрочерноземы (275 мг/кг). Это обусловлено выходом на поверхность нижележащих менее гумусированных почвенных горизонтов, илистые фракции которых обогащены смектитовым компонен- 
Бюллетень Почвенного института им. В.В. Докучаева. 2016. Вып. 84.

том, способствующим увеличению количества сорбированного твердой фазой почвы фосфора.

Ключевые слова: органические и органо-глинистые комплексы почвы, одноточечная изотерма сорбции фосфора, эрозия почвы.

DOI: $10.19047 / 0136-1694-2016-84-75-100$

\section{ВВЕДЕНИЕ}

Фосфор является одним из необходимых элементов для произрастания растений и количество доступного растениям фосфора в почвах часто бывает неадекватным требованиям растений.

Содержание фосфора в почве обусловлено двумя основными процессами: сорбцией и осаждением фосфат-ионов, которые контролируют доступность Р в почвах и тесно связано с сорбционной емкостью почвы (Lajtha, Harrison, 1995; del Campillo et al. 1999). Специфическая адсорбция (лигандный обмен) наблюдается при замещении анионами фосфора гидроксильных групп на поверхности оксидов и гироксидов $\mathrm{Al}$ и Fe (Haynes, Mokolobate, 2001). В литературе имеются многочисленные данные об изменении сорбционной емкости фосфора и его десорбционного потенциала в удобряемых почвах (Afif et al., 1993; Sharpley et al., 1994; Sharpley, 1995; Delgado, Torrent, 2000; Zhou, Li, 2001; Koopmans et al., 2004). Реакции осаждения происходят при образовании нерастворимых фосфорсодержащих компонентов.

Сорбция фосфора в почвах - ключевой процесс, управляющий его доступностью для растений. Она зависит от минералогических и химических свойств почвы. Эти параметры отдельно или в комбинации влияют на сорбционную или десорбционную способность фосфора в почве.

В числе минералогических параметров следует отметить тип и количество глинистых минералов, $\mathrm{CaCO}_{3}, \mathrm{Al}$ и $\mathrm{Fe}$ (Dodor, Oya, 2000; Burt et al., 2002; Giesle et al., 2005).

Одним из главных факторов, влияющих на сорбционные свойства по отношению к фосфат-ионам, является органическое вещество почвы. Влияние органического вещества на динамику в почве фосфора проявляется двояко: посредством снижения сорбционной способности почв по отношению к фосфору и как прямой источник фосфатов, образующихся при минерализации фосфорорганических соединений. В литературе имеется множество данных 
Бюллетень Почвенного института им. В.В. Докучаева. 2016. Вып. 84.

об увеличении количества доступного фосфора растениям и снижении сорбционной способности почв, в частности при внесении органических удобрений (Iyamuremye et al., 1996; Nziguheba et al., 1998; Whalen et al., 2000; Erich et al., 2002). Это происходит в силу кумулятивного эффекта нескольких механизмов, которые включают высвобождение неорганических соединений фосфора из разлагающихся растительных остатков, блокирование сорбционных позиций органическими молекулами, высвобождающимися из растительных остатков, повышения $\mathrm{pH}$ почвы, связывания растворимых $\mathrm{Al}$ и Fe органическими молекулами (Iyamuremye, Dick, 1996; Sharpley et al., 1985; Erich et al., 2002).

Однако роль отдельных факторов и механизмов в формировании сорбционных свойств почв еще остается дискуссионной. Особенный интерес представляет изучение сорбционных характеристик продуктов органо-минеральных взаимодействий в почве. Наиболее важную роль с точки зрения участия в формировании фосфатного режима почв играют органо-глинистые комплексы (илистая фракция) и легкие фракции (ЛФ) (продукты органоминерального взаимодействия (ПОМВ), которые являются важнейшими составляющими почвенного поглощающего комплекса, определяющего химические и физико-химические свойства почвы и формирующего основное ее жизнеобеспечивающее свойство плодородие (Артемьева, 2015).

В связи с этим представляется перспективным использование характеристик органо-минеральных фракций эродированных почв в качестве дополнительного диагностического признака эрозионных процессов. Изменение состояния элементов питания в почве в условиях развития эрозионных процессов, часто вследствие интенсивной системы земледелия, и разработка диагностических показателей для оценки их уровня остается важной проблемой сельского хозяйства.

Известные экстрактивные методы определения обеспеченности почв фосфором часто оказываются недостаточно информативными, поскольку не позволяют учесть индивидуальные особенности почв, связанные с закреплением элементов (Иванов и др., 2012). Большое разнообразие существующих методов создает дополнительные трудности в сравнительной оценке их содержания в почвах различного генезиса и стадии эволюции в антропоге- 
Бюллетень Почвенного института им. В.В. Докучаева. 2016. Вып. 84.

незе. Эти недостатки особенно рельефно проявляются в ландшафтном подходе к оценке плодородия почв, поскольку в почвенном покрове нередко сочетаются почвы с резко различающимися свойствами. Усовершенствование методов диагностики фосфорного состояния почв может быть достигнуто с помощью использования физико-химических методов, в частности изучения кинетики сорбции фосфат-иона на примере изотерм сорбции фосфора. Метод обладает неоспоримым преимуществом перед независимыми вытяжками, поскольку в отличие от них обеспечивает сравнение различных по свойствам почвенных разностей. Однако при всей очевидности преимуществ он достаточно трудоемок. Поэтому в 1977 г. Д. Джонсом в соавторстве с Р. Фоксом (Jones, Fox, $\underline{1977)}$ был предложен метод одноточечной изотермы. Вся процедура значительно упрощается и сводится к методу построения изотермы сорбции по двум точкам, одна из которых - нулевая.

Изотерма сорбции фосфора представляет источник получения целого комплекса параметров: концентрации равновесного раствора

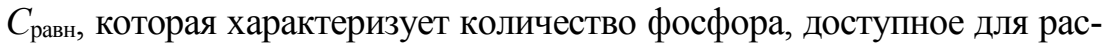

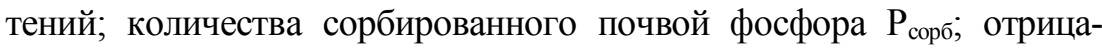
тельный отрезок изотермы сорбции характеризует количество лабильного фосфора в равновесном растворе Рлаб и буферную способность почвы по отношению к фосфат-ионам, характеризующую способность почвы поддерживать концентрацию фосфора в растворе на постоянном уровне (определяется по тангенсу угла наклона изотермы к оси $x$ ). Таким образом, одноточечную изотерму можно рассматривать как информативный экспресс-метод получения параметров сорбции фосфат-ионов. Этот метод с успехом применяется за рубежом для исследования почв (ㅂenry, Smith, 2003, 2006).

Цель работы - изучить фосфатный режим почв зонального ряда Русской равнины разных элементарных почвенных структур с использованием физико-химических методов.

\section{ОБЪЕКТЫ И МЕТОДЫ}

Исследования проводили на представительных объектах старопахотных почв в зональном ряду агроландшафтов Русской равнины: в южно-таежной подзоне дерново-подзолистых почв (Зеленоградский стационар Почвенного института им. В.В. Докучаева); серых лесных почв (опорный пункт Почвенного 
Бюллетень Почвенного института им. В.В. Докучаева. 2016. Вып. 84.

института им. В.В. Докучаева "Иваньково”, опытно-полевое хозяйство Владимирского НИИ сельского хозяйства); черноземах (Центрально-Черноземный заповедник, Петринский опорный пункт Почвенного института им. В.В. Докучаева, опытное хозяйство Всероссийского НИИ земледелия и защиты почв от эрозии).

В подзоне дерново-подзолистых почв исследования почвенных катен с различными вариантами развития эрозионных процессов проводили на трех представительных склонах длительного сельскохозяйственного использования регионального полигона “Зеленоградский”, более подробно описанных в работах Н.П. Сорокиной (2003), Е.И. Саввиновой (1982).

В зоне серых лесных почв исследования проводили на двух представительных склонах агроландшафта длительного сельскохозяйственного использования, более подробно описанных в работах Н.П. Сорокиной (2003) и Е.В. Шеина (Путеводитель научных полевых экскурсий III съезда Докучаевского общества почвоведов, 2000).

В зоне черноземов исследования вели на двух склонах длительного сельскохозяйственного использования, более подробно описанных в работах Н.В. Денисовой (1974), Н.П. Сорокиной (2003), И.И. Васенева (2003).

Для выделения органических и органо-глинистых комплексов использовали модифицированный вариант гранулоденсиметрического метода (Шаймухаметов, Травникова, 1984; Травникова, Артемьева, 2001; Артемьева, 2010). Легкие фракции выделяли по упрощенной схеме с помощью бромоформэтанольной смеси плотностью 2.0 и 1.8 г/ $\mathrm{cm}^{3}$ после того как из почвы после предварительного 15-минутного воздействия ультразвука на почвенную суспензию (77 Дж/мл) удалили ил.

Содержание углерода определяли методом мокрого сжигания по Тюрину. Для изучения фосфатного режима использовали метод одноточечной изотермы сорбции фосфора.

Построение одноточечной изотермы сорбции. Две навески воздушно-сухой почвы заливали $0.01 \mathrm{M} \mathrm{CaCl}_{2}$ в соотношении $1: 100$ в тефлоновых пробирках. В одну из них добавляли известное количество фосфора в виде $\mathrm{KH}_{2} \mathrm{PO}_{4}$. Нами опробован и уточнен данный экспресс-метод для качественно различных групп органических и органо-минеральных составляющих почвы. Проведя 
Бюллетень Почвенного института им. В.В. Докучаева. 2016. Вып. 84.

ряд экспериментов по выбору оптимальной концентрации добавляемого фосфора для построения второй точки изотермы сорбции фосфат-иона в целях универсализации метода для разных органоминеральных фракций остановились на величине 15 мкг Р/мл (в виде $\mathrm{KH}_{2} \mathrm{PO}_{4}$ ) (Артемьева, 2008).

Суспензию обрабатывали ультразвуком на установке УЗДН$2 \mathrm{~T}$ зондового типа (77 Дж/мл) в течение 3 мин. Обработанную суспензию выстаивали 12 ч (оставляли на ночь), после чего центрифугирули в течение 10 мин при скорости 3000 об./мин. Концентрацию фосфора в равновесном растворе определяли колориметрически. Количество сорбированного фосфора вычисляли по разности между его содержанием в исходном и равновесном растворах. Строили изотерму по двум точкам, первая из которых является нулевой, по ней находили количество лабильного фосфора в равновесном растворе.

\section{РЕЗУЛЬТАТЫ И ОБСУЖДЕНИЕ}

Сумма компонентов почвенного поглощающего комплекса (ППК) в исследованных почвах зонального ряда полнопрофильных почв центра Русской равнины увеличивается в ряду: агродерново-подзолистые $(16.9 \pm 0.6 \%)<$ агросерые почвы $(20.8 \pm 1.3 \%)<$ $<$ агрочерноземы $(28.5 \pm 0.9 \%)$ (табл. 1). Из них на долю илистых фракций приходится от $15.0 \pm 0.9$ (агродерново-подзолистые) и $17.7 \pm 1.5$ (агросерые почвы) до $24.9 \pm 0.7 \%$ (агрочерноземы), легких фракций - от $1.9 \pm 0.4$ (агродерново-подзолистые) и $3.1 \pm 0.2$ (агросерые почвы) до $3.6 \pm 0.8 \%$ (агрочерноземы). В них сосредоточено 65-75\% органического вещества почв. Компоненты ППК представлены тонкодисперсными частицами в отличие от фракции остатка, где преобладают крупнодисперсные и более окристаллизованные оксиды, что сильно ограничивает их сорбционную способность.

Исследование параметров сорбции компонентов, составляющих ППК и фракции остатка, показало, что для илистых фракций зонального ряда несмытых почв Центра Русской равнины величина равновесной концентрации фосфора $\left(C_{\text {равн }}\right)$ в $0.01 \mathrm{M}$ растворе $\mathrm{CaCl}_{2}$ уменьшается в ряду: агродерново-подзолистые почвы $(1.0 \pm 0.1$ мкг $\mathrm{P} / \mathrm{Mл})>$ агросерые почвы $(0.6 \pm 0.3$ мкг $\mathrm{P} / \mathrm{Mл})>$ агрочерноземы $-0.5 \pm 0.1$ мкг $\mathrm{P} / \mathrm{Mл}$. 
Бюллетень Почвенного института им. В.В. Докучаева. 2016. Вып. 84.

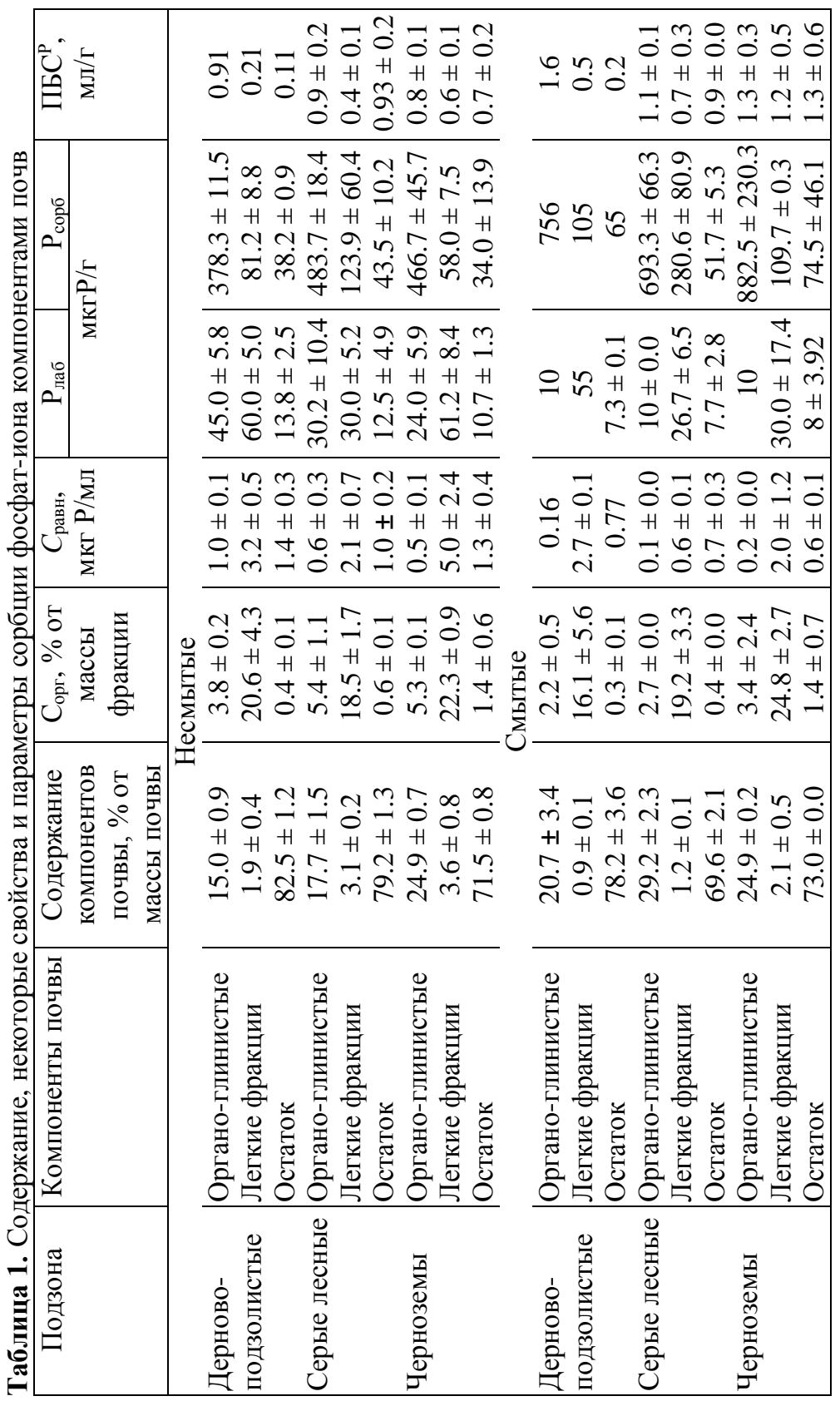


Бюллетень Почвенного института им. В.В. Докучаева. 2016. Вып. 84.

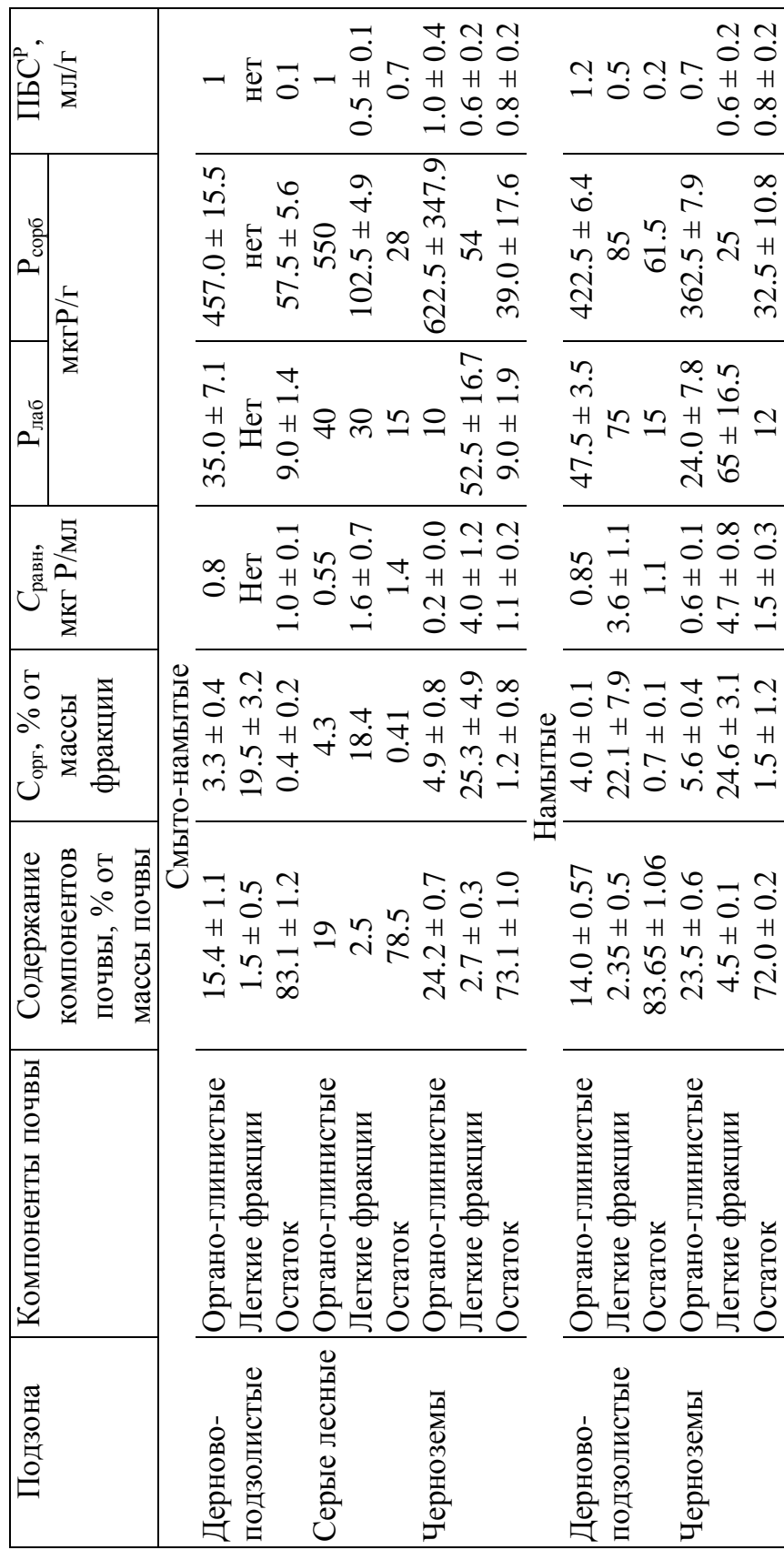


Бюллетень Почвенного института им. В.В. Докучаева. 2016. Вып. 84.

Развитие эрозионных процессов способствует значительному

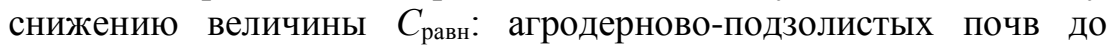
$0.2 \pm 0.0, \quad$ агросерых почв $0.1 \pm 0.1, \quad$ агрочерноземов $0.2 \pm 0.0$ мкг Р/мл.

Для смыто-намытых и намытых почвенных разностей отмечено увеличение значений величины $C_{\text {равн }}$ : для агродерновоподзолистых почв до $0.8 \pm 0.0$, агросерых почв до $0.5 \pm 0.0$, для агрочерноземов она остается без изменения, до $0.2 \pm 0.0$ мкг Р/мл.

Выявлена прямая зависимость между концентрацией равновесного раствора фосфора и содержанием углерода в илистых фракциях зонального ряда почв центра Русской равнины: для агродерново-подзолистых почв $r=0.95$ при $P=0.0002$, агросерых $r=$ $=0.95$ при $P<0.0003$, агрочерноземов $r=0.93$ при $P=0.0002$ (рис. 1).

Таким образом, для илистых фракций зонального ряда почв центра Русской равнины очевидно резкое уменьшение (в 3-7 раз) величины равновесной концентрации фосфора с развитием денудационных процессов. Это связано с тем, что с интенсификацией денудационных процессов на поверхность выходят более глубокие почвенные горизонты, менее гумусированные и обогащенные смектитовым компонентом, а также оксидами железа(III) и алюминия(III), что усиливает фосфат-фиксирующую способность почв. Соответственно, чем выше степень смытости почвы, тем меньше величина равновесной концентрации фосфора.

Закономерности распределения лабильного фосфора (Р лаб) в илистых фракциях почв различной локализации на склоне аналогичны таковым для $C_{\text {равн. }}$.

Количество фосфора, накапливаемого в твердой фазе в результате его внесения в почву, рассчитано при значении равновесной концентрации 5 мкг/мл. Наиболее низкими значениями $\mathrm{P}_{\text {сорб }}$ среди исследованных илистых фракций почв разных элементарных почвенных структур характеризуются несмытые, смыто-намытые и намытые почвы: для агродерново-подзолистых - $378.3 \pm 11.5$, $457.0 \pm 15.5$ и $422.5 \pm 6.4$ мкг/Г соответственно, агросерых $483.7 \pm 18.4, \quad 550 \pm 0.0$ мкг $/$, агрочерноземов $-466.7 \pm 45.7$, $622.5 \pm 34.7$ и $362.5 \pm 7.9$ мкг/г фракции соответственно.

Илистые фракции смытых почв отличаются максимальны-

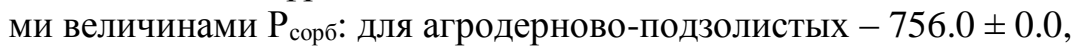


Бюллетень Почвенного института им. В.В. Докучаева. 2016. Вып. 84.

A
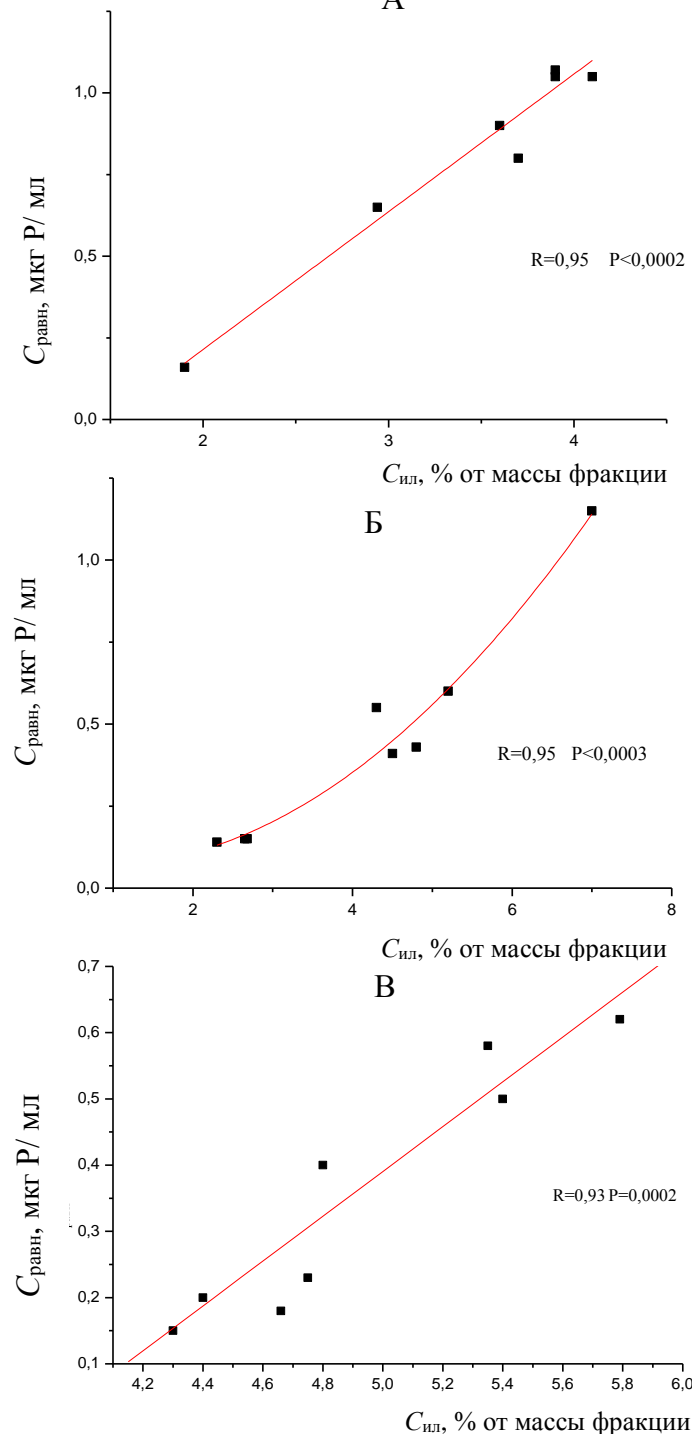

Рис. 1. Графики зависимости $C_{\text {равн }}$ от концентрации углерода в илистой фракции агродерново-подзолистых (А), агросерых (Б), агрочерноземов (В). 
Бюллетень Почвенного института им. В.В. Докучаева. 2016. Вып. 84.

агросерых - 693.3 \pm 66.3 , агрочерноземов - $882.5 \pm 23.0$ мкг/г фракции. Количество сорбированного твердой фазой илистых фракций фосфора обратно пропорционально концентрации углерода в илистых фракциях зонального ряда почв центра Русской равнины: для агродерново-подзолистых почв $r=-0.77$ при $P=$ 0.002 , агросерых $r=-0.82$ при $P<0.001$, агрочерноземов $r=-0.92$ при $P=0.0003$ (рис. 2).

Величина ПБС ${ }^{\mathrm{P}}$ характеризует буферную способность почвы по отношению к фосфат-ионам. Наименьшие величины ПБС отмечены для илистых фракций несмытых почвенных разновидностей: для агродерново-подзолистых и агросерых почв эта величина составляет $0.9 \pm 0.2$, агрочерноземов $-0.8 \pm 0.1 \mathrm{мл} /$.

В смытых почвах этот показатель достигает максимальных величин: для агродерново-подзолистых $1.6 \pm 0.0$, агросерых почв $1.1 \pm 0.1$, агрочерноземов $1.3 \pm 0.3$ мл/г.

Смыто-намытые и намытые почвенные разности характери-

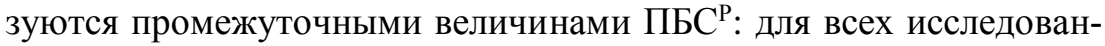
ных почв он составляет $1.0 \pm 0.0 \ldots 1.0 \pm 0.4$ мл/г.

Легкие фракции, органическое вещество которых не связано прочными химическими связями с глинистыми минералами, по параметрам сорбции-десорбции фосфат-ионов существенно отличаются от илистых. Они характеризуются значительно бо́льшими величинами $C_{\text {равн }}$ по сравнению с илистыми фракциями. Величина $C_{\text {равн }}$ в несмытых почвах зонального ряда почв центра Русской равнины составляет для агродерново-подзолистых $3.2 \pm 0.5$, агросерых почв $-2.1 \pm 0.7$, агрочерноземов $-5.0 \pm 2.4$ мкг Р/мл.

В смытых почвах величина $C_{\text {равн }}$ снижается: для агродерновоподзолистой почвы она составляет $2.7 \pm 0.1$, агросерых $-0.6 \pm 0.1$, агрочерноземов $-2.0 \pm 1.2$ мкг $\mathrm{P} /$ мл.

Для смыто-намытых и намытых почв зонального ряда отмечается

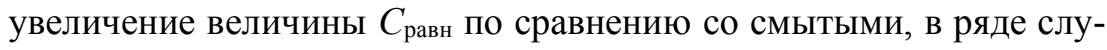
чаев превышая таковые для несмытых разновидностей: для намытой агродерново-подзолистой почвы величина $C_{\text {равн }}$ составляет $3.6 \pm 1.1$, смыто-намытой агросерой почвы $1.6 \pm 0.7$, смытонамытых и намытых агрочерноземов - $4.0 \pm 1.2$ и $4.7 \pm 0.8$ мкг $\mathrm{P} /$ мл соответственно.

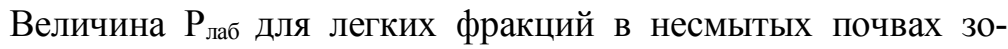
нального ряда почв центра Русской равнины колеблется в пределах 
Бюллетень Почвенного института им. В.В. Докучаева. 2016. Вып. 84.
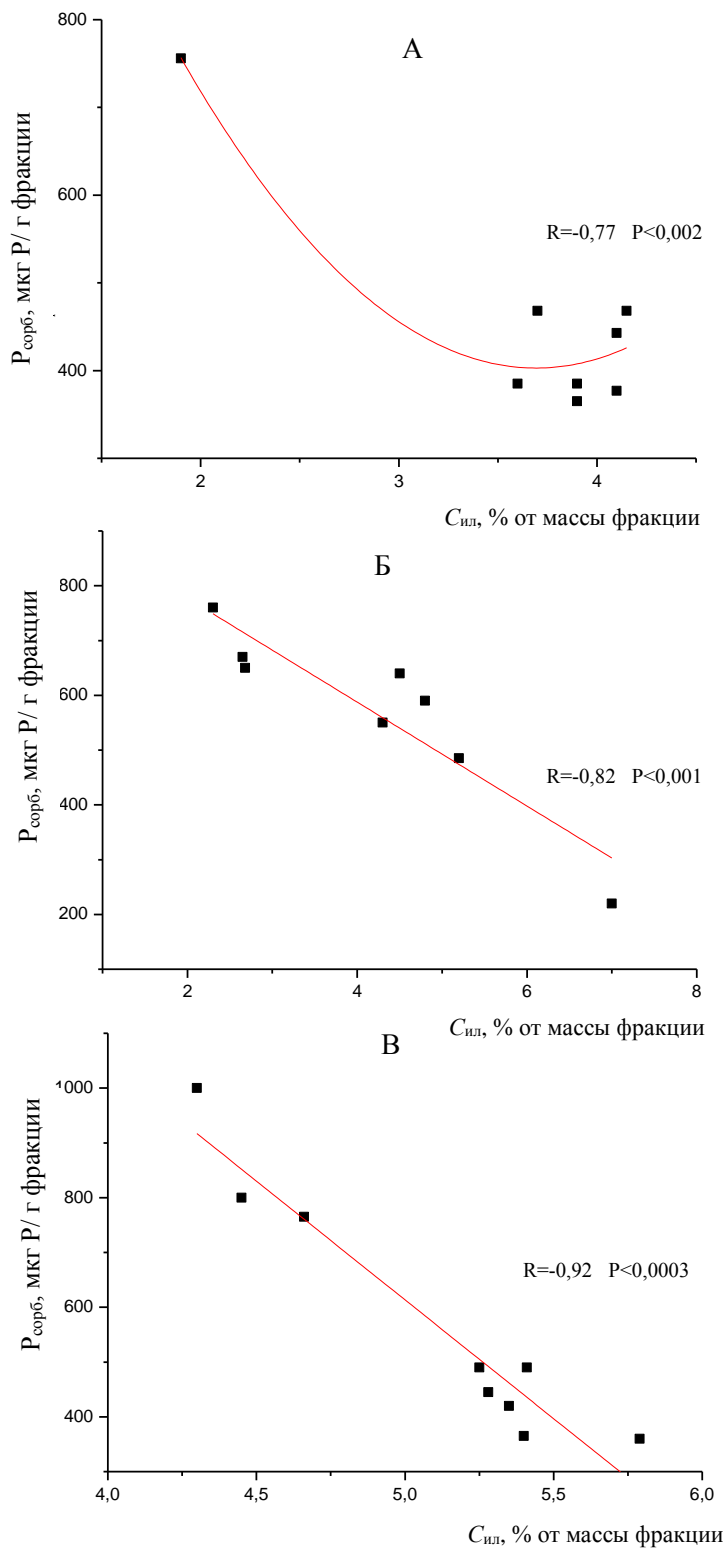

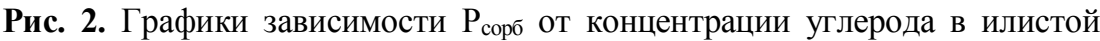
фракции агродерново-подзолистых (А), агросерых (Б), агрочерноземов (В). 
Бюллетень Почвенного института им. В.В. Докучаева. 2016. Вып. 84.

30-60 мкг Р/г фракции и составляет для агродерново-подзолистых $60 \pm 5$, агросерых почв $30 \pm 5$ и агрочерноземов $61 \pm 8$ мкг $\mathrm{P} / г$ фракции. С развитием эрозионных процессов она снижается до 55 (агродерново-подзолистые почвы), $26.7 \pm 6.5$ (агросерые почвы) и $30 \pm 17.4$ мкг Р/г фракции (агрочерноземы).

Для смыто-намытых и намытых почв зонального ряда отме-

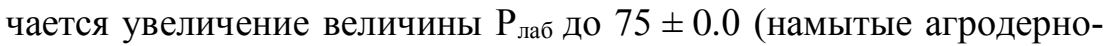
во-подзолистые почвы), $53 \pm 16.7$ и $65.0 \pm 16.5$ мкг Р/Г фракции (смыто-намытые и намытые агрочерноземы соответственно).

Количество фосфора, накапливаемого в твердой фазе легких фракций в результате его внесения в почву, рассчитано при универсальном значении равновесной концентрации 5 мкг $\mathrm{P} / \mathrm{мл.} \mathrm{Ве-}$ личина сорбированного фосфат-иона в полнопрофильных почвах зонального ряда почв центра Русской равнины колеблется в пределах 58-124 мкг/г фракции и составляет $81 \pm 8.8$ (агродерновоподзолистые), $124 \pm 60.4$ (агросерые) и $58 \pm 7.5$ мкг/г фракции (агрочерноземы).

Максимальные величины отмечены для смытых почв: 105 (агродерново-подзолистые), $281 \pm 80.9$ (агросерые) и $110 \pm 46.1$ мкг/Г фракции (агрочерноземы). Для смыто-намытых и намытых почв величины сорбированного фосфат-иона уменьшаются по сравнению со смытыми почвами до 54-103 мкг/г фракции. Как и следовало ожидать, легкие фракции характеризуются существенно меньшими величины ПБС ${ }^{\mathrm{P}}$ по сравнению с илистыми: (0.21$0.4) \pm 0.1$ (несмытые агродерново-подзолистые и агросерые почвы), $0.6 \pm 0.1 \quad$ (агрочерноземы), $(0.5-1.2) \pm 0.5 \quad$ (смытые почвы), $0.5 \pm 0.1 \ldots 0.6 \pm 0.2$ (смыто-намытые и намытые почвы).

Таким образом, легкие фракции по сравнению с илистыми обладают большей способностью выделять фосфат-ионы в раствор и существенно меньшей способностью к его сорбции.

Величина $C_{\text {равн }}$ для фракции остатка несмытых разновидностей зонального ряда почв центра Русской равнины составляет для агродерново-подзолистых почв - $1.4 \pm 0.3$, агросерых почв $1.0 \pm 0.2$, агрочерноземов $-1.3 \pm 0.4$ мкг Р/мл.

В смытых почвах величина $C_{\text {равн }}$ снижается: для агродерново-подзолистой почвы она составляет $0.77 \pm 0.0$, агросерых почв $0.7 \pm 0.3$, агрочерноземов $-0.6 \pm 0.0$ мкг Р/мл. 
Бюллетень Почвенного института им. В.В. Докучаева. 2016. Вып. 84.

Смыто-намытые и намытые почвы зонального ряда характе-

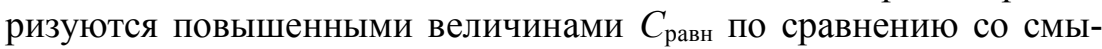
тыми, в ряде случаев превышая таковые для полнопрофильных разновидностей: для смыто-намытых и намытых агродерновоподзолистых почв величина $C_{\text {равн }}$ составляет $1.0 \pm 0.1$ и $1.1 \pm 0.0$ мгк Р /мл соответственно, смыто-намытой агросерой почвы - 1.4 мгк Р/мл, смыто-намытых и намытых агрочерноземов $1.1 \pm 0.2$ и $1.5 \pm 0.3$ мкг Р/мл соответственно.

Фракция остатка характеризуется наименьшими величинами $\mathrm{P}_{\text {лаб }}$ среди органо-минеральных фракций. В полнопрофильных почвах исследованного зонального ряда величина Рлаб составляет для агродерново-подзолистых почв - $13.8 \pm 2.5$, агросерых почв $-12.5 \pm 4.9$, агрочерноземов $-10.7 \pm 1.3$ мкг $\mathrm{P} / \Gamma$ фракции.

С развитием эрозионных процессов величина $\mathrm{P}_{\text {лаб }}$ снижается: для агродерново-подзолистых почв до $7.3 \pm 0.1$, агросерых почв до $7.7 \pm 2.8$, агрочерноземов до $8.0 \pm 3.9$ мкг Р/г фракции.

Смыто-намытые и намытые почвы зонального ряда характеризуется повышенными величинами Р лаб по сравнению со смытыми, в ряде случаев превышая таковые для несмытых разновидностей: для смыто-намытых и намытых агродерново-подзолистых

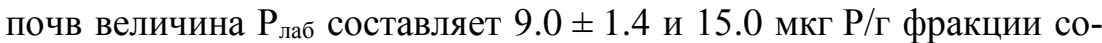
ответственно, смыто-намытой агросерой почвы - 15, смытонамытых и намытых агрочерноземов $-9.0 \pm 1.9$ и 12.0 мкг Р/г фракции соответственно.

Фракция остатка характеризуется также наименьшими значениями величины $\mathrm{P}_{\text {сорб }}$ среди органо-минеральных фракций (рассчитано при универсальном значении равновесной концентрации 5 мкг/мл. В несмытых разновидностях исследованных почв величины сорбированного фосфат-иона достигают: в агродерновоподзолистых почвах $-38 \pm 0.9$, в агросерых почвах $-44 \pm 10.2$, в агрочерноземах - $34 \pm 13.9$ мкг $\mathrm{P} / \Gamma$ фракции.

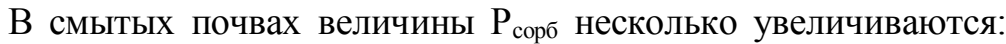
для агродерново-подзолистых до 65.0, агросерых до $51.7 \pm 5.3$, агрочерноземов до $74.5 \pm 46.1$ мкг $\mathrm{P} / \Gamma$ фракции.

Для смыто-намытых и намытых почвенных разностей отме-

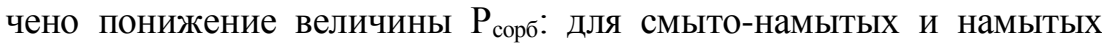
агродерново-подзолистых почв она составляет $58 \pm 5.6$ и 62 мкг $\mathrm{P} / \Gamma$ фракции, соответственно, для смыто-намытой агросерой почвы - 
Бюллетень Почвенного института им. В.В. Докучаева. 2016. Вып. 84.

28 мкг Р/г фракции, для смыто-намытых и намытых агрочерноземов $-39 \pm 17.6$ и $33 \pm 10.8$ мкг Р/г фракции, соответственно.

Величина ПБС ${ }^{\mathrm{P}}$ для фракции остатка исследованных несмытых разновидностей зонального ряда почв составляет: для агродерново-подзолистых 0.1 , агросерых почв $1.0 \pm 0.2$, агрочерноземов $0.7 \pm 0.2$ мкг $\mathrm{P} / \Gamma$ фракции.

В смытых почвах величина ПБС ${ }^{\mathrm{P}}$ увеличивается: для агродерново-подзолистых она составляет 0.16, агросерых почв $0.94 \pm 0.0$, агрочерноземов $-1.3 \pm 0.6 \mathrm{мл} / \Gamma$.

Смыто-намытые и намытые почвенные разности характеризуются промежуточными величинами ПБС : для смыто-намытой и намытой агродерново-подзолистых почв она составляет 0.1 и 0.2 , смыто-намытой агросерой почвы - 0.7, смыто-намытых и намытых агрочерноземов $-0.8 \pm 0.2 \mathrm{мл} / \Gamma$.

Таким образом, исследования показали, что в целом компоненты ППК (илистые и легкие фракции) обладают более высокой сорбционной способностью и способностью выделять фосфор в раствор по сравнению с фракцией остатка. Фракция остатка харак-

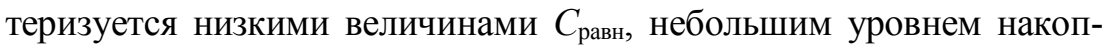
ления фосфора в твердой фазе и буферной способностью.

Составляющие ППК включают в себя практически все поверхности с вариабельным зарядом, обладающие способностью сорбировать анионы, т.е. именно эти компоненты почвы ответственны за регулирование ее фосфатного режима на основе сорбции-десорбции (Травникова, Петрова, 1988). Об этом свидетельствуют весьма высокие корреляционные зависимости между показателями сорбции фосфат-иона и содержанием в них органического вещества. Следует отметить, что илистые фракции почв отличаются лучшей способностью удерживать фосфат-ионы и меньшей способностью выделять их в раствор по сравнению с легкими фракциями. В отличие от этих составляющих изменение параметров, характеризующих изотермы сорбции фракции остатка, не коррелирует с изменением факторов сорбции.

Оценивая роль отдельных компонентов почвы в формировании уровня растворимых фосфатов, выявили следующее: в исследованных зонального ряда несмытых почвах центра Русской равнины вклад компонентов ППК примерно равен вкладу остатка и колеблется от 40-49\% от общего уровня накопления растворимого 
Бюллетень Почвенного института им. В.В. Докучаева. 2016. Вып. 84.

фосфора в почве (табл. 2). Можно сделать вывод, что содержание растворимых фосфатов в несмытых почвах может регулироваться в равной мере как десорбцией из компонентов ППК, так и процессами растворения их минеральных соединений.

Развитие эрозионных процессов способствует снижению долевого участия компонентов ППК в накоплении растворимого фосфора в почве: для агродерново-подзолистых смытых почв эта величина снижается до $30 \pm 0.4 \%$ (более чем в 1.4 раза), для агрочерноземов - до $34 \pm 0.6 \%$ от $\mathrm{P}_{\text {лаб }}{ }^{\text {почв }}$ ( 1.5 раза). Для агросерых почв доля компонентов ППК снизилась незначительно - до $35 \pm 4.6 \%$ от общего уровня накопления растворимого фосфора в почве. Соответственно относительно увеличилась доля фракции остатка (65-

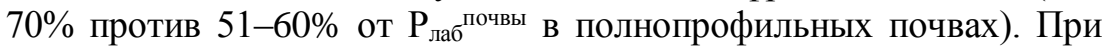
агрогенно-активизированных эрозионных процессах количество растворимых фосфатов в почве в большей степени может регулироваться растворением минеральных соединений, а не десорбцией их из компонентов ППК.

Как показали исследования, легкие фракции обладают более выраженной способностью возобновлять запасы растворимых фосфатов по сравнению с илистыми фракциями. Последнее объясняется не только тем, что эти составляющие выделяют большее количество фосфатов на единицу массы, но и тем, что фосфаты связаны с поверхностью их адсорбционной фазы с наименьшей для всех компонентов ППК энергией связи (Травникова, Петрова, 1988). Однако их доля в накоплении растворимых фосфатов невелика и составляет не более 5-6\% от суммы компонентов ППК (агродерновоподзолистые и агросерые) и существенно больше в агрочерноземах (13\% от суммы компонентов ППК). В эродированных почвах абсолютные количества и доля участия металлогуминовых составляющих ППК снижаются: для агросерых почв до $3.1 \%$ (в 2 раза), агрочерноземов до $6.6 \%$ (в 2 раза).

Анализ имеющихся материалов позволяет предполагать, что за лабильный фосфор компонентов ППК ответственна органическая фаза. Это подтверждается наличием прямой зависимости между содержанием органического вещества (\% от массы фракции) и содержанием растворимого фосфора соответствующих компонентов, $r=-0.67$ при $P<0.001$ (рис. 3). 
Бюллетень Почвенного института им. В.В. Докучаева. 2016. Вып. 84.

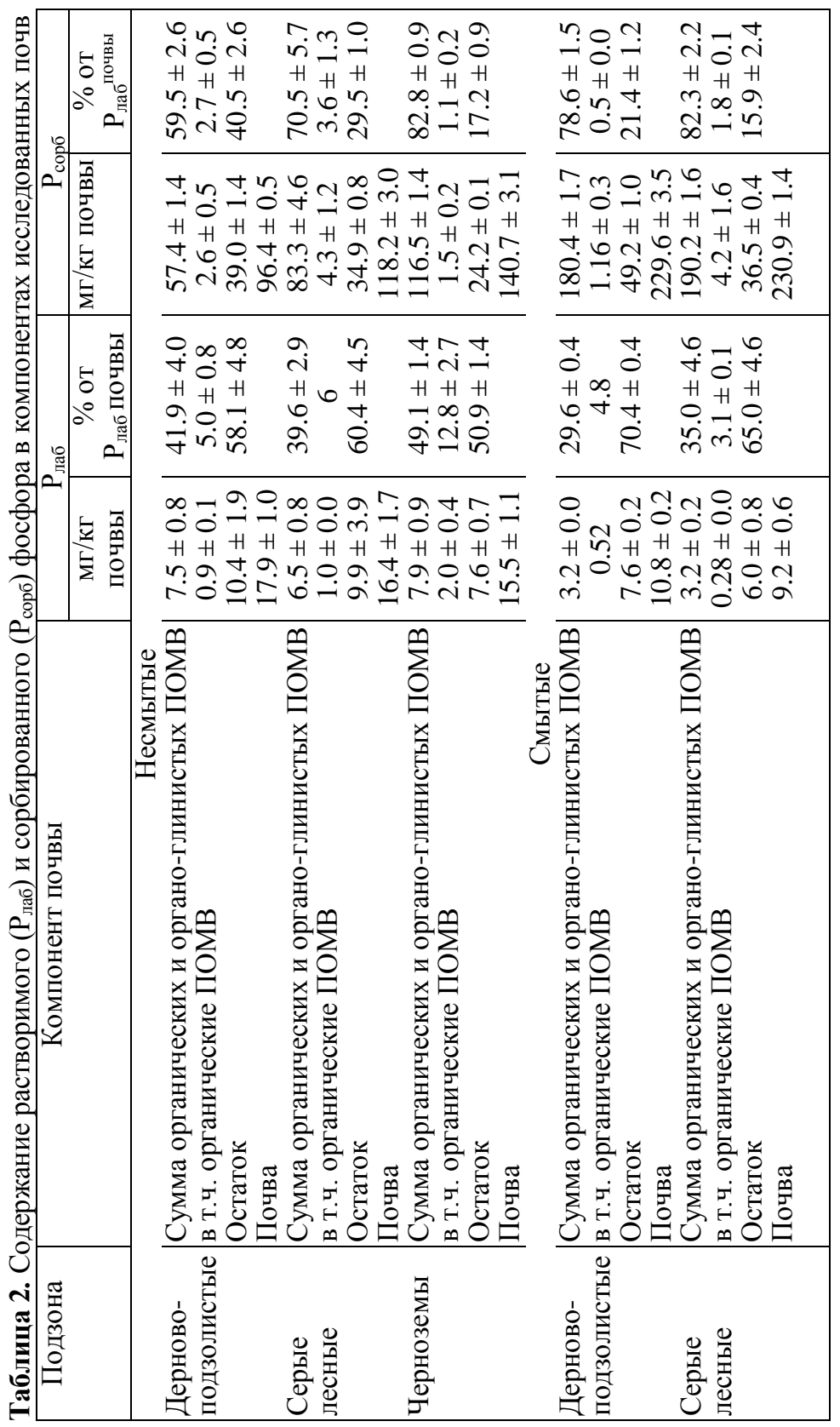


Бюллетень Почвенного института им. В.В. Докучаева. 2016. Вып. 84.

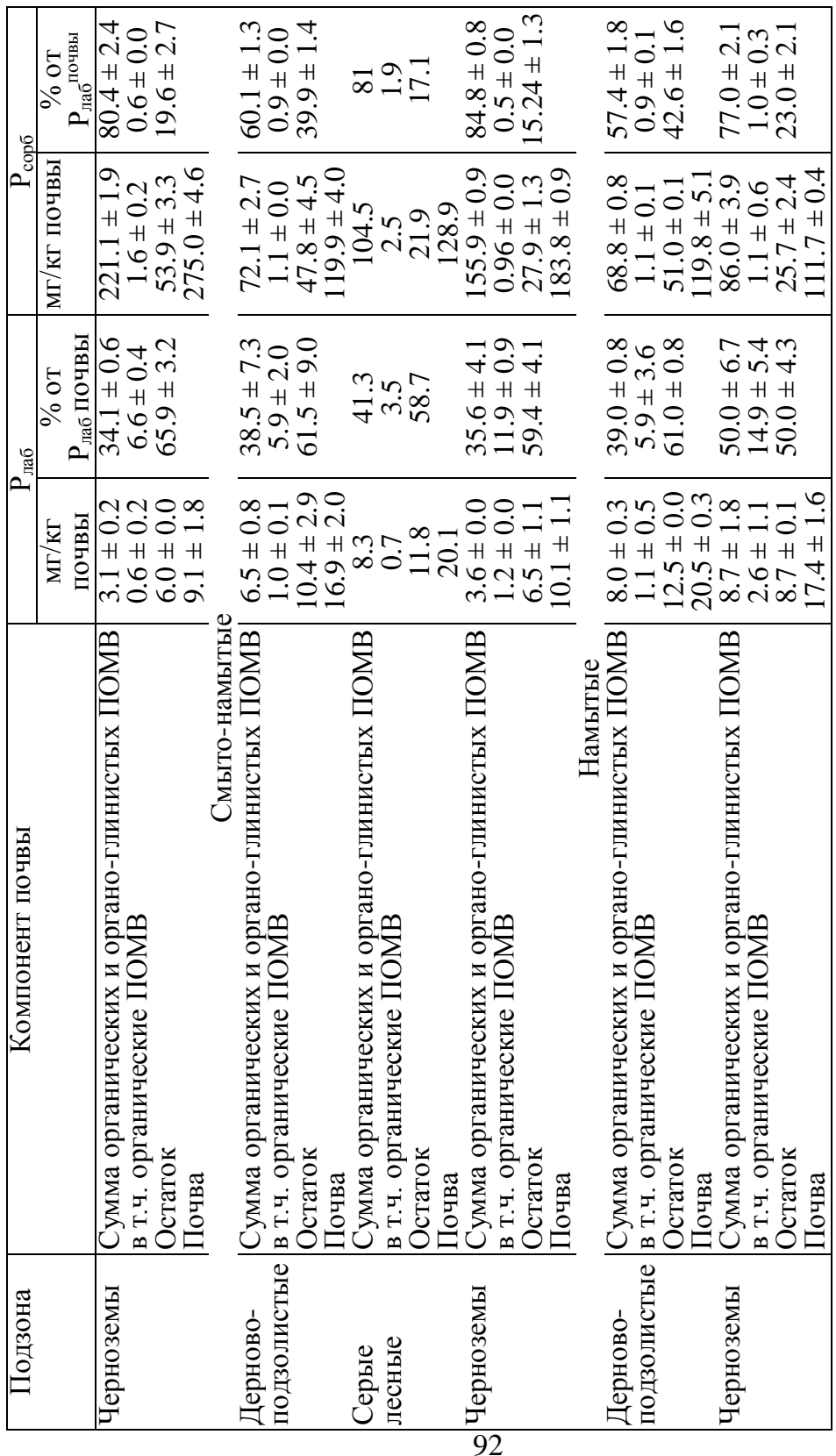


Бюллетень Почвенного института им. В.В. Докучаева. 2016. Вып. 84.

Оценивая роль отдельных компонентов почвы в процессах сорбции фосфора, выявили следующее. По вкладу компонентов ППК исследованные полнопрофильные почвы центра Русской равнины составляют ряд: агродерново-подзолистые $(59.5 \pm 2.6 \%)<$ $<$ агросерые $(70.5 \pm 5.7 \%)<$ агрочерноземы $(82.8 \pm 0.9 \%)$.

Развитие эрозионных процессов способствует увеличению долевого участия компонентов ППК в накоплении сорбированного фосфора в почве: для агродерново-подзолистых смытых почв эта величина повышается до $79 \pm 1.5 \%$ (почти в 1.3 раза), агросерых почв до $82 \pm 2.2 \%$ (почти в 1.2 раза), для агрочерноземов остается практически той же $(80 \pm 2.4 \%)$. Соответственно относительно снижается доля фракции остатка (16-21\% против 17-40\% в несмытых почвах). Следовательно, с определенной долей уверенности можно утверждать, что накопление фосфора в твердой фазе полнопрофильных почв осуществляется сорбционными процессами, нежели механизмом осаждения.

Агрогенно-обусловленные эрозионные процессы способствуют дальнейшему повышению доли сорбционных процессов накопления фосфора в твердой фазе, за счет обнажения нижних горизонтов, обедненных органическим веществом и обогащенных смектитовым компонентом. Легкие фракции почвы принимают минимальное участие в процессах сорбции фосфора: их долевое участие колеблется в пределах от 0.3 до 3\%. Можно предполагать, что в широком ряду равновесных концентраций, они лишь десорбируют фосфаты.

Количество сорбированного фосфора в твердой фазе обратно пропорционально концентрации углерода в компонентах ППК почв $-r=-0.7$ при $P<0.0001$ (рис. 4).

Таким образом, продукты органо-минерального взаимодействия обеспечивают значительную часть доступных растениям фосфатов в почве. Органические составляющие ППК (ЛФ) поставляют доступные фосфаты в основном за счет содержащихся в них растворимых соединений, которые высвобождаются в процессе минерализации, и в меньшей мере за счет процессов обмена ионов почвенного раствора и ионами функциональных групп. Участие органо-глинистых комплексов ППК (илистых фракций) осуществляется за счет процессов сорбции-десорбции. 
Бюллетень Почвенного института им. В.В. Докучаева. 2016. Вып. 84.

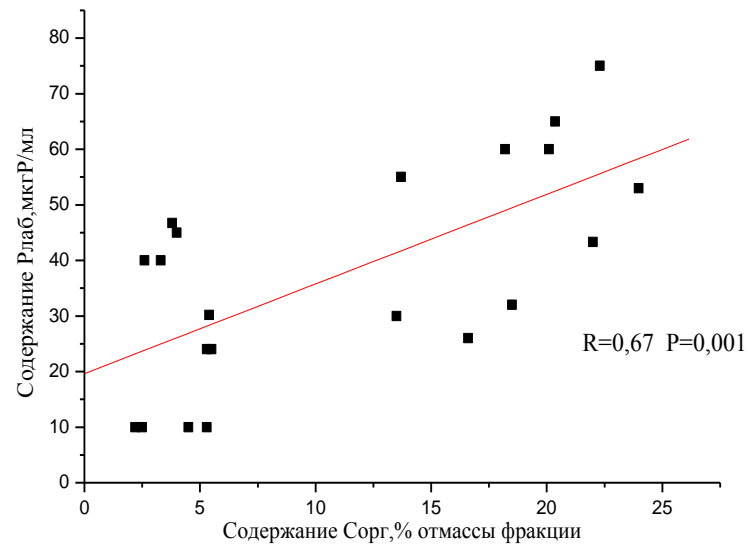

Рис. 3. Зависимость $\mathrm{P}_{\text {лаб }}$ от С орг фракции.

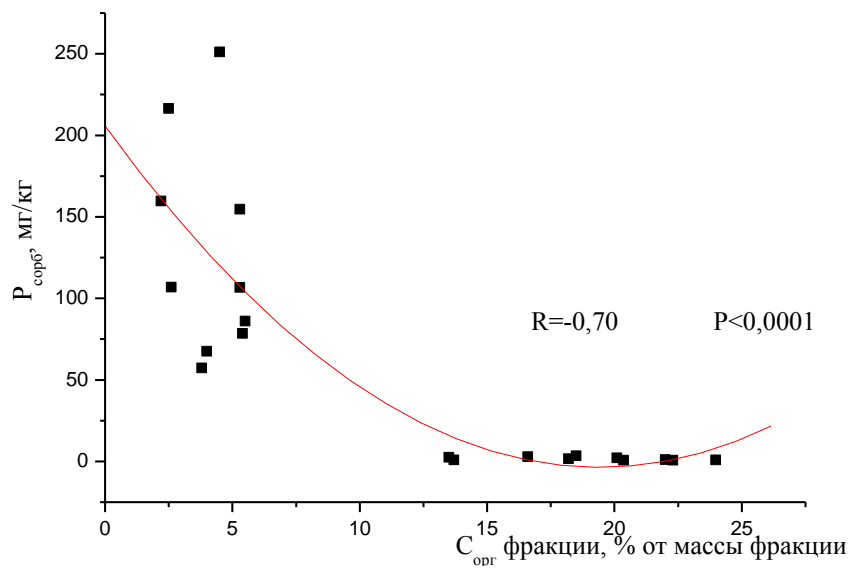

Рис. 4. Зависимость $\mathrm{P}_{\text {сорб }}$ от $\mathrm{C}$ орг фракции.

Фракция остатка участвует в накоплении доступных фосфатов процессами растворения-осаждения минеральных соединений.

\section{ЗАКЛЮЧЕНИЕ}

Полученные параметры сорбции фосфат-иона органоминеральных фракций, использованные в качестве критерия для оценки фосфатного режима, свидетельствуют о высокой подвижности фосфора в неэродированных почвах: для агродерново- 
Бюллетень Почвенного института им. В.В. Докучаева. 2016. Вып. 84.

подзолистых почв $\mathrm{P}_{\text {лаб }} 18 \pm 1.0$, агросерых почв $16 \pm 1.7$, агрочерноземов $16 \pm 1.1$ мг/кг; $\mathrm{P}_{\text {сорб }}$ составляет для агродерновоподзолистых почв $96 \pm 0.5$, агросерых почв $118 \pm 3.0$, агрочерноземов - $141 \pm 3.1$ мг/кг (рис. 5). Они характеризуются более выраженной способностью поддерживать постоянный уровень доступных для растений фосфатов.

Почвы, подвергшиеся эрозии, характеризуются значительно более неблагоприятным фосфатным режимом. Они отличаются высокой сорбционной способностью по отношению к фосфатиону, сорбционные характеристики меняются в сторону увеличения прочности связывания фосфат-ионов, уменьшения количества доступного растениям фосфора: для агродерново-подзолистых почв $\mathrm{P}_{\text {лаб }}=10.8 \pm 0.2$, агросерых почв $9.2 \pm 0.6$, агрочерноземов -

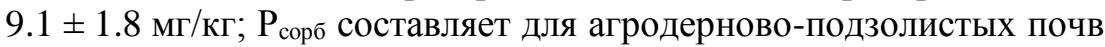
$230 \pm 3.5$, агросерых почв - $231 \pm 1.4$, агрочерноземов $275 \pm 4.6$ мг/кг (рис. 6).

Это обусловлено выходом на поверхность нижележащих менее гумусированных почвенных горизонтов, илистые фракции которых обогащены смектитовым компонентом, способствующим увеличению количества сорбированного твердой фазой почвы фосфора. Соответственно, смытые почвы характеризуются значительно меньшей устойчивостью в целом.

Процессы наносонакопления способствуют улучшению сорбционных параметров почвы, что выражается в увеличении количества лабильного фосфора в растворе и уменьшения фосфоpa, сорбированного твердой фазой почвы: для агродерновоподзолистых почв $\mathrm{P}_{\text {лаб }}=21 \pm 0.3$, агросерых почв -20 , агрочерноземов - $17 \pm 1.6$ мг/кг; $\mathrm{P}_{\text {сорб }}$ составляет для агродерновоподзолистых почв - $120 \pm 5.1$, агросерых почв 129 мг/кг, агрочерноземов - $112 \pm 0.4$ мг/кг. Однако почвы зоны преимущественной аккумуляции (намытые), как правило приуроченные к нижним частям склонов, часто функционируют в условиях периодического повышенного увлажнения, что определяет уровень накопления органического вещества, превышающий экологически обусловленный. Поэтому, хотя данные почвенные разновидности можно считать устойчивыми к деградации, они могут представлять угрозу с экологической точки зрения, в частности, за счет возможной 
Бюллетень Почвенного института им. В.В. Докучаева. 2016. Вып. 84.

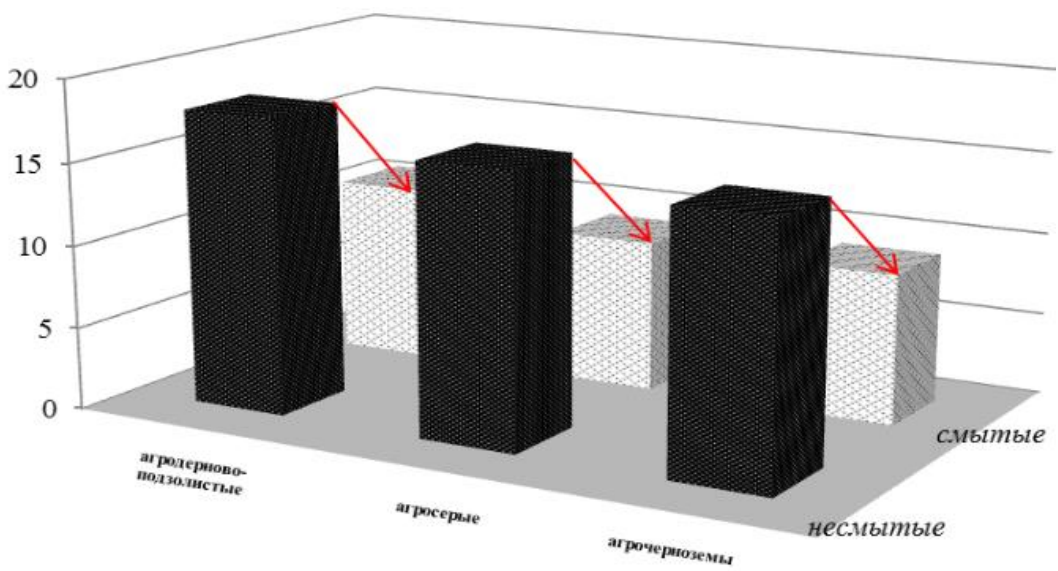

Рис. 5. Диаграмма изменения содержания $\mathrm{P}_{\text {лаб }}$ (мг/кг) в зональном ряду почв Русской равнины в процессе агрогененно-эрозионных процессов.

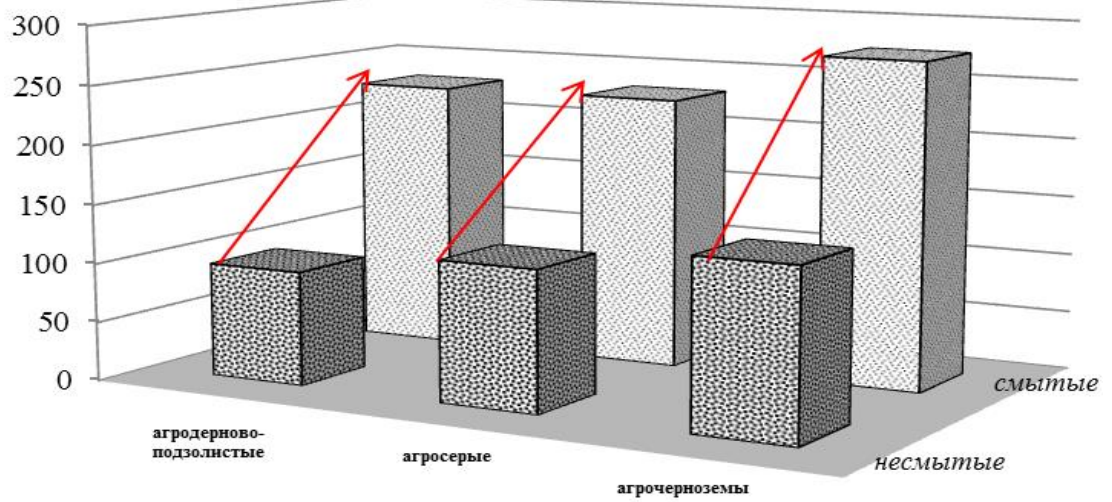

Рис. 6. Диаграмма изменения содержания $\mathrm{P}_{\text {сорб }}$ (мг/кг) в зональном ряду почв Русской равнины при агрогененно-эрозионных процессах.

миграции за пределы почвенного профиля и нарушения экологического равновесия в ландшафте.

Таким образом, характеристики сорбции фосфат-иона органо-минеральных фракций изученных зонального ряда склоновых почв Русской равнины являются информативным компонентом при оценке фосфатного состояния эрозионно-деградированных почв. 
Бюллетень Почвенного института им. В.В. Докучаева. 2016. Вып. 84.

Благодарность. Работа выполнена при финансовой поддержке Президиума РАН (грант на проведение фундаментальных исследований в 2015 г.) и гранта РНФ №14-26-00079.

\section{СПИСОК ЛИТЕРАТУРЫ}

1. Аринушкина Е.В. Руководство по химическому анализу почв. М.: Издво Моск. ун-та, 1970.487 с.

2. Артемьева 3.С. Органические и органо-глинистые комплексы агрогенно-деградированных почв. Дис. ... д. б. н. М., 2008. 359 с.

3. Артемьева 3.С. Органическое вещество и гранулометрическая система почвы. М.: ГЕОС, 2010. 240 c.

4. Артемьева 3.С. Роль органических и органо-минеральных составляющих в формировании фосфатного режима пахотных горизонтов эрозионно-деградированных агродерново-подзолистых почв // Бюл. Почв. ин-та им. В.В. Докучаева. 2015. Вып. 78.С. 70-86

5. Васенев И.И. Анализ средневременной динамики черноземов антропогенно измененных лесостепных экосистем. Курск, 2003. 120 с.

6. Денисова Н.В. Формы неоднородности покрова в черноземной зоне Европейской части Союза (Средне-Русская и Заволжская провинции). Дис. ... к. с.-Х. н. М., 1974. 164 с.

7. Иванов А.Л., Сычев В.Г., Державин Л.М., Адрианов С.Н., Бражникова Н.В., Карпова Д.В., Карпухин А.И., Кирпичников Н.А., Конончук В.Д., Самойлов Л.Н. Агробиогеохимический цикл фосфора. М.: Россельхозакадемия, 2012. $512 \mathrm{c.}$

8. Путеводитель научных полевых экскурсий III съезда Докучаевского общества почвоведов. Суздаль-М., 2000. 118 с.

9. Саввинова Е.И. Агрономические особенности и продуктивность дерново-подзолистых почв на разных элементах рельефа // Почвенноагрономическое районирование и агрономическая характеристика почв основных регионов СССР. Науч. тр. Почв. ин-та им. В.В. Докучаева, 1982. C. $38-48$

10.Сорокина Н.П. Структура почвенного покрова пахотных земель: типизация, картография, агроэкологическая оценка. Дис. ... д. с.-х. н. М., 2003. $278 \mathrm{c}$.

11.Травникова Л.С., Артемьева 3.С. Физическое фракционирование органического вещества почв с целью изучения его устойчивости к биодеградации // Экология и почвы. Избр. лекции 10-й Всерос. школы. T. IV. Пущино, 2001. С. 337-346.

12.Травникова Л.С., Петрова Л.В. Роль продуктов органо-минерального взаимодействия в формировании фосфатного режима дерново- 
Бюллетень Почвенного института им. В.В. Докучаева. 2016. Вып. 84.

подзолистой почвы // Физико-химия почв и их плодородие. М., 1988. С. 39-47.

13.Шаймухаметов М.Ш., Травникова Л.С. Способ извлечения из почвы поглощающего комплекса // Авт. св-во №1185238. Госком. СССР по делам изобретений и открытий. Заявка №3732977. Приоритет изобр. 30.03.1984.

14.Afif E., Matar A., Torren J. Availability of phosphate applied to calcareous soils of West Asia and North Africa // Soil Sci. Soc. Am. J. 1993. V. 57. P. 756-760.

15.Burt R., Mays M.D., Benham E.C., Wilson M.A. Phosphorus characterization and correlation with properties of selected benchmark soils of the United States // Commum. Soil Sci. Plant Anal. 2002. V. 33. P. 117-141.

16.Del Campillo M.C., van der Zee S.E.A.T.M., Torrent J. Modelling longterm phosphorus leaching and changes in phosphorus fertility in excessively fertilized acid sandy soils // Europ. J. Soil Sci. 1999. V. 50(3). P. 391-399.

17. Delgado A., Torrent J. Phosphorus forms and desorption patterns in heavily fertilized calcareous and limed acid soils // Soil Sci. Soc. Am. J. 2000. 64. P. 2031-2037.

18.Dodor D.E., Oya K. Phosphate sorption characteristics of major soils in Okinawa, Japan // Commun. Soil. Sci. Plant Anal. 2000. V. 31. P. 277-288.

19.Erich M.S., Fitzgerald C.B., Porter G.A. The effect of organic amendments on phosphorus chemistry in a potato cropping system // Agriculture, Ecosystems and Environment. 2002. 88. P. 79-88.

20. Giesler R., Anderson L., Lovgren L., Persson P. Phosphate sorption in aluminium-and iron-rish humus soils // Soil Sci. Soc. Am. J. 2005. V. 69. P. 77 86.

21.Haynes R.J., Mokolobate M.S. Amelioration of Al toxicity and $\mathrm{P}$ deficiency in acid soils by additions of organic residues: a critical review of the phenomenon and the mechanisms involved // Nutrient Cycling Agroecosystems J. 2001. V. 59. P. 47-63.

22.Henry P.C., Smith M.F. A single point sorption test for the routine determination of the phosphorus requirement of low to moderate P-fixing soils // S. Afr. Tydskr. Plant Grond. 2003. V. 20(3). P. 132-140.

23.Henry P.C., Smith M.F. Two-step approach to determining some useful phosphorus characteristics of South African soils: a review of work done at the ARC-Institute for Soil, Climate and Water // S. Afr. Tydskr. Plant Grond. 2006. V. 23(1). P. 64-72.

24.Iyamuremye F., Dick R.P., Baham J. Organic amendments and phosphorus dynamics: I. Phosphorus chemistry and sorption // Soil Sci. 1996. V. 161. 7. P. 426-435. 
Бюллетень Почвенного института им. В.В. Докучаева. 2016. Вып. 84.

25.Jones J.P., Fox R.L. Phosphate sorption as a soil testing technique: a simplified approach // Commun. Soil Sci. Plant Analysis. 1977. V. 8(3). P. 209219.

26. Koopmans G.F., Chardon W.J., de Willigen P., van Riemsdijk W.H. Phosphorus desorption dynamics in soil and the link to a dynamic concept of bioavailability // J. Environ. Qual. 2004. V. 33. P. 1393-1402.

27. Lajtha K., Harrison A.F. Strategies of phosphorus acquisition and conservation by plant species and communities // Phosphorus in the global environment: Transfers, cycles, and management. SCOPE 54 / Ed. Tiessen H. 1995. P. 139-147.

28.Nziguheba G., Palm C.A., Buresh R.J., Smithson P.A. Soil phosphorus fractions and sorption as affected by organic and inorganic sources // Plant and Soil. 1998. V. 198. P. 159-168.

29. Sharpley A.N. Dependence of runoff phosphorus on extractable soil phosphorus // J. Environ. Qual. 1995. V. 24. P. 920-926.

30.Sharpley A.N., Chapra S.C., Wedepohl R., Sims J.T., Daniel T.C., Reddy K.R. Managing agricultural phosphorus for protection of surface waters: Issues and options // J. Environ. Qual. 1994. V. 23. P. 437-451.

31. Sharpley A.N., Smith S.J. Fractionation of inorganic and organic phosphorus in virgin and cultivated soils // Soil Sci. Soc. Am. J. 1985. V. 49. P. 127136.

32. Whalen J.K., Chang C., Clayton W., Carefoot P. Cattle manure amendments can increase the $\mathrm{pH}$ of acid soils // Soil Sci. Soc. Am. J. 2000. 64. P. 962-966.

33.Zhou M., Li Y. Phosphorus-sorption characteristics of calcareous soils and limestone from the Southern Everglades and adjacent farmlands // Soil. Sci. Soc. Am. J. 2001. V. 65. P. 1404-1412.

\title{
THE ORGANIC AND ORGANO-MINERAL COMPONENTS OF PHOSPHATE REGIME OF ERODED SOILS IN THE CENTRE OF RUSSIAN PLAIN
}

\author{
Z. S. Artemyeva ${ }^{1}$, N. P. Kirillova ${ }^{1,2}$, \\ T. M. Sileova ${ }^{2}$, Ye. I. Soshnikova ${ }^{1,2}$ \\ ${ }^{1}$ V.V. Dokuchaev Soil Science Institute, \\ Russia, 119017, Moscow, Pyzhevskii 7, bld. 2 \\ ${ }^{2}$ Lomonosov Moscow State University, \\ Russia, 119991, Moscow, 1 Leninskiye Gory
}

The phosphate state of arable layers of eroded soils from the Centre of Russian plain was investigated. The investigation was conducted at the background of the parameters of sorption of phosphate-ion from different components of the 
organic matter. In terms of the assessment of the phosphate state of eroded soils was shown the informativity of phosphate-ion sorption characteristics of organic and organo-mineral fractions. The organic and organo-mineral fractions of the arable layers of non-eroded soils from the zonal range are characterized by the high level of phosphorus mobility and their ability to support the constant level of phosphates available for plants: agrosoddy-podzolic soils $(17.9 \pm 1.0 \mathrm{mg} / \mathrm{kg}) \rightarrow$ agrogray soils $(16.4 \pm 1.7 \mathrm{mg} / \mathrm{kg}) \rightarrow$ agrochernozems $(15.5 \pm 1.1 \mathrm{mg} / \mathrm{kg}) . \quad \mathrm{P}_{\mathrm{oc}}$ forms a range: agrosoddy-podzolic soils $(96.4 \pm 0.5 \mathrm{mg} / \mathrm{kg}) \rightarrow$ agrogray soils $(118.2 \pm 3.0 \mathrm{mg} / \mathrm{kg}) \rightarrow$ agrochernozems $(140.7 \pm 3.1 \mathrm{mg} / \mathrm{kg})$. In the Centre of Russian Plane, among the investigated zonal soils with maximal humus saturation of clay fractions, the soils with full profile within this complex are the most sustainable to erosion in conditions of particular ecologic situation. Agroecological features of eroded soils are increased sorption of phosphate-ion. The sorption characteristics alter in the direction of increasing the strength of phosphate-ion binding, reducing the amount of available phosphorus to plants: for agrosoddy-podzolic soils $\mathrm{P}_{\text {lab }}$ $10.8 \pm 0.2 \mathrm{mg} / \mathrm{kg}$, for agrogray soils $-9.2 \pm 0.6 \mathrm{mg} / \mathrm{kg}$, for agrochernozems $9.1 \pm 1.8 \mathrm{mg} / \mathrm{kg} . \quad \mathrm{P}_{\text {oc }}$ forms a range: agrosoddy-podzolic soils $(229.6 \pm 3.5 \mathrm{мг} / \mathrm{\kappa}) \rightarrow$ agrogray soils $(230.9 \pm 1.4 \mathrm{мг} / \mathrm{\kappa}) \rightarrow$ agrochernozems $(275.0 \pm 4.6 \mathrm{mg} / \mathrm{kg})$. This is due to the exposure of lower layers less humified, clay fractions which are enriched in the smectite component, contributing to an increase in the quantity of sorbed phosphorus soil solid phase. Therefore, in general, eroded soils are characterized by significantly lower sustainability, and, in particular, energetically less balanced phosphorus cycle.

Keywords: organic and organo-clayey soil complexes, single point phosphorus sorption isotherm, soil erosion. 